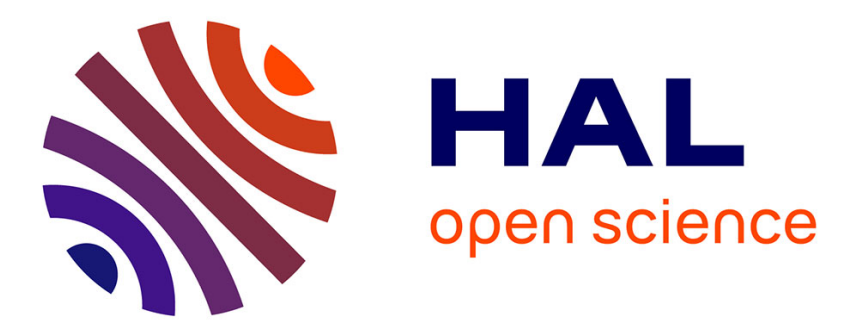

\title{
STABILITY OF POLYACETYLENE DOPED BY ION IMPLANTATION
}

\author{
J. Davenas, X. Xu, M. Maitrot, M. Gamoudi, G. Guillaud, J. André, B. \\ François, C. Mathis
}

\section{- To cite this version:}

J. Davenas, X. Xu, M. Maitrot, M. Gamoudi, G. Guillaud, et al.. STABILITY OF POLYACETYLENE DOPED BY ION IMPLANTATION. Journal de Physique Colloques, 1983, 44 (C3), pp.C3183-C3-188. 10.1051/jphyscol:1983337 . jpa-00222689

\section{HAL Id: jpa-00222689 https://hal.science/jpa-00222689}

Submitted on 1 Jan 1983

HAL is a multi-disciplinary open access archive for the deposit and dissemination of scientific research documents, whether they are published or not. The documents may come from teaching and research institutions in France or abroad, or from public or private research centers.
L'archive ouverte pluridisciplinaire HAL, est destinée au dépôt et à la diffusion de documents scientifiques de niveau recherche, publiés ou non, émanant des établissements d'enseignement et de recherche français ou étrangers, des laboratoires publics ou privés. 


\title{
STABILITY OF POLYACETYLENE DOPED BY ION IMPLANTATION
}

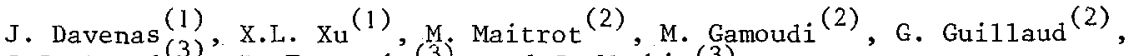 \\ J.J. André ${ }^{(3)}$, B. François ${ }^{(3)}$ and C. Mathis $(3)$
}

(1) Département de Physique des Matériaux, 43 Bld du 11 Novembre, 69622 Vizleurbanne Cedex, France

(2) Laboratoire de Physique Electronique, 43 Bld du 11 Novembre, 69622 Vilzeurbanne Cedex, France

(3) Centre de Recherche sur les Macromolécules, 6 Rue Boussingault, 67083 Strasbourg Cedex, France

\begin{abstract}
Résumé - L'introduction d'impuretês dopantes dans des polymères tels que $(\mathrm{CH}){ }_{x}$ permet d'induire des'propriétés semiconductrices de type $\mathrm{p}$ ou $\mathrm{n}$, ou même un régime de conduction métallique lorsque I'on augmente la concentration. Nous présentons de nouveaux résultats concernant la stabilité du polyacétylène dopé par implantation d'ions, vis à vis: (1) de la dégradation induite par l'irradiation ionique (2) de l'oxydation et (3) des traitements thermiques. Deux types de techniques ont êté utilisêes dans ce but: (1) la modification des propriétés êlectriques et (2) 1a microanalyse nucléaire pour la dêtermination du profil de distribution des différents éléments chimiques. En particulier, 1a résonance à $6385 \mathrm{keV}$ de l'azote 15 a été utilisée pour déterminer la composition en hydrogène de la matrice en fonction de la profondeur. La répartition des différentes espèces dopantes et son évolution au cours des traitements a étê étudiée par rétrodiffusion Rutherford.
\end{abstract}

\begin{abstract}
The introduction of doping impurities in polymers such as $(\mathrm{CH}) \mathrm{x}$ can induce $n$ or $p$ type semiconducting properties or a metallic regime when $x$ increasing the concentration. We present some new results on the stability of (CH) films doped by ion implantation, in respect to: (1) the degradation induce by the ionic irradiation, (2) oxidation, (3) thermal annealings. For that purpose two types of techniques have been used (1) modification of the electrical conductivity and (2) nuclear microanalysis for depth profiling of the different elements. In particular the nuclear resonance at $6385 \mathrm{keV}$ of ${ }^{15} \mathrm{~N}$ was used to determine the hydrogen composition of the matrix as a function of the depth. The repartition of the different doping species and the evolution with annealings was studied by Rutherford Backscattering Spectroscopy (RBS).
\end{abstract}

I - INTRODUCTION

The interest of ion implantation for the synthesis of new materials has been demonstrated during these last years by the number of papers devoted to this topic. The major advantage of this technique is the possibility of doping a material with any impurity irrespectively of diffusion laws and accurate aljustement of the local composition. However the primary effects of implantation are often followed by backreactions and materials synthetized by this technique are generally in a metastable equilibrium. For that reason stability is a fundamental problem in implantation. Ion implantation appeared in the last decades as a powerfull technique for the doping of mineral semiconductors and was tested recently as a new method /1,2,3,4/ of doping in the case of semiconducting polymers. Among these polymers, polyacetylene has been extensively studied because it was the first to be synthetized in a processable form and because it can be easily doped by chemical means. The low redox potential of polyacetylene accounts for the easiness of ( $\mathrm{CH}$ ) doping which may be a probiem because of the difficulty to avoid dop ing by impurities, in particular of the catalyser used in its synthesis and by the oxygen of the air. From that point of view, ion implantation may appear as a clean procedure of doping, but has the disadvantage of producing defects which may induce a degradation of the material. The last problem is the thermal stability 
of the doping species which must stay reasonable for temperatures ranging $100^{\circ} \mathrm{C}$ since this is the domain of operating temperatures which may be met in electronic devices. We have then considered the three following aspects: (1) stability of polyacetylene towards ionic irradiation

(2) stability of implanted ( $\mathrm{CH})$ in respect to oxidation

(3) thermic stability of the implant

II - EXPERIMENTAL

The $(\overline{\mathrm{CH}})$ films were grown at the CRM Strasbourg (CNRS) in the usual way $/ 5 /$ on a Ziegler-Natta layer of catalyst solution $/ 6 /$. The purity of intrinsic polyacetylene has been characterized by Rutherford Backscattering Spectroscopy at the Département de Physique des Matériaux and the electrical conductivity, which was studied at the Laboratoire de Physique Electronique, showed a close connection between the measured values and the concentration of residual impurities remaining from the catalysis /7/. Improvment of the preparation procedure (slow processing and several washings) leaded to low surface conductivities ( $\sigma \leqslant 10^{-14} \Omega \mathrm{cm}$ ) for samples exhibiting no detectable traces of catalyser in the vicinity of the surface. Polyacetylene has been completely isomerized into transpolyacetylene by a thermal treatment at $150^{\circ} \mathrm{C}$ during about $15 \mathrm{~min}$. The polyacetylene films were implanted at liquid nitrogen temperature in order to limit the rate of defect creation. Two electrodes were evaporated after implantation on the irradiated surface of the film for conductivity measurements. The measure of the conductivity of the implanted layer, which is difficult because of its thin and buried nature, was possible because of the diffusion of the evaporated electrodes in the film which was demonstrated by RBS. This diffusion allowed a good contact between the electrodes and the doped layer.

A nuclear reaction was used in order to determine the hydrogen profile. The microanalysis was done at the Institut de Physique Nucléaire de Lyon with the help of a beam of doubly charged nitrogen ions produced in a $4 \mathrm{MeV}$ Van de Graaf.

\section{III - STABILITY TOWARDS IONIC IRRADIATION}

During the implantation the accelerated particles loose their kinetic energy in the target according to various mechanisms which are responsible of the defect creation. The energy exchanges depend upon the masses and relative energies of incident and target particles and may be considered are quite similar for two successive elements in the periodical table. Then same rates of defect creation are to be expected for implantations, with chlorine and argon ions at the same energy, and differences in the properties of two samples implanted in such conditions must be attributed to the nature of the implanted chemical species. Figure 1 shows the current-voltage curves of two samples implanted with $3.10^{15} \mathrm{CI}^{-}$and $\mathrm{I}^{-}$ions at $50 \mathrm{keV}$ on a log-log scale. We observe two main properties:

- a modification of the contact properties which become ohmic and which may be connected to the irradiation itself

- different electrical activities of the two implanted species showing evidence for a doping effect of chlorine ions

However polymers are reputed to be very sensitive to irradiations and a degradation of the material has been shown to occur, in some cases with a complete carbonization of the samples /9/. As example of an application of such an effect, ion beams have been used as the incident radiation in lithography for the etching of resists $/ 10 /$. In order to evaluate the maximum damage which may be met in such irradiations, we have determined the hydrogen composition of a $(\mathrm{CH})$ film implanted with 10 $\mathrm{Ar}$ ions $/ \mathrm{cm}^{2}$ at $50 \mathrm{keV}$. The local concentration of Argon atoms is then of 
the 15 rder of $20 \%$. For that purpose we used the resonance at $6385 \mathrm{keV}$ of ${ }^{15}$ on target hydrogen according to the nuclear reaction:

$$
15_{\mathrm{N}}+{ }^{1} \mathrm{H} \rightarrow{ }^{12} \mathrm{C}+\alpha+\gamma
$$

By varying the incident energy of the nitrogen beam it is then possible to shift the resonance deeper inside the sample and the variation of the intensity of the emitted $\gamma$ signal allows the reconstruction of the hydrogen profile. A non irradiated sample is used as reference. The profile presented in figure 3 shows that all the irradiated thickness has been severely damaged since the hydrogen deficit is larger than $50 \%$. In the implantation thickness the hydrogen concentration is reduced of about one half. Another surprising fact is the extent of the deficit zone which is 10 times larger than the ion range and which is not consistent with the assumption of an equal depth used by the Motorola Group in the study of the degradation of various organic resists by the measurs of the gas outgassing from the sample /10/.

\section{IV - OXIDATION OF IMPLANTED POLYACETYLENE}

The oxidation of two samples, a reference and a sample originating in the same film which has been implanted with $5.10^{16}$ iodine ions $/ \mathrm{cm}^{2}$ at $100 \mathrm{keV}$, was studied by Rutherford Backscattering spectroscopy. In this technique, a beam of light particles accelerated at some MeV is used as a probe to determine the distribution of heavy atoms in a light matrix. From the energy distribution of the elastically scattered particles it is possible to deduce the profile of the impurities such as the implanted ions or the oxygen due to the sample contamination after exposure to the air. In table 1 we have gathered the oxygen concentrations (oxygen to matrix carbon ratio) as a function of the total time of exposure to the air for an implanted and a prystine sample. These concentrations have been calculated by the integration of the total number of oxygen atoms and its ratio to the corresponding number of carbon atoms taken into two different zones:

- one referred as the surface, corresponding to the irradiated layer, the thickness of which has been chosen equal to $4000 \AA$ (mean range of implanted ions: $3000 \AA$, half width of the distribution of doping ions: $1000 \AA$ ).

- the other as the volume, which must mostly reflect the properties of the bulk, the width of which has been limited to $15000 \AA$.

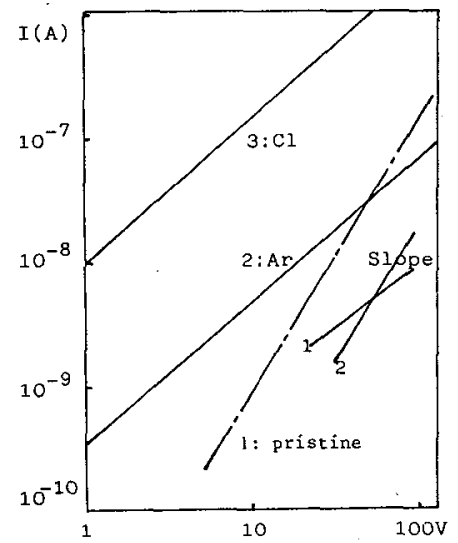

Figure 1: current-voltage curves of (CH) samples: (1) pristine, (2) implan with $3.10^{15} \mathrm{Cl} / \mathrm{cm}^{2}$ at $50 \mathrm{keV}$

(3) implanted with $3.10^{15} \mathrm{I}^{-} / \mathrm{cm}^{2}$ at $100 \mathrm{keV}$.

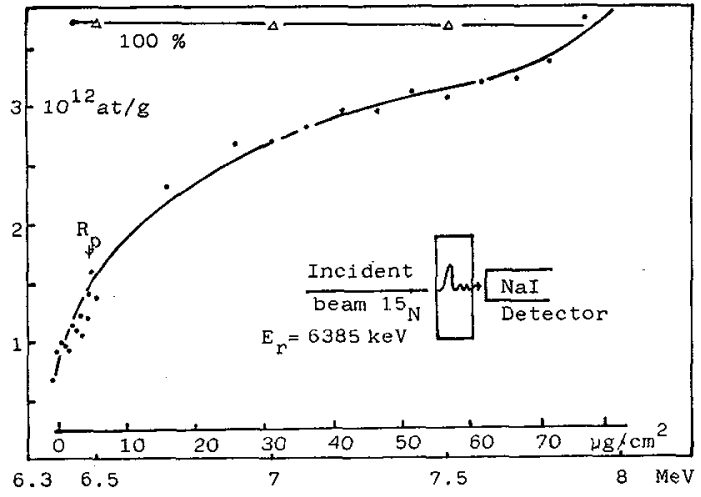

Figure 2: hydrogen profile of a (CH) $x$ sample: $(\Delta)$ pristine, (.) implanted with $10^{17}$ Argon $/ \mathrm{cm}^{2}$ at $50 \mathrm{keV}$. 


\begin{tabular}{|c|c|c|c|c|}
\hline $\begin{array}{c}\text { TOTAL TIME } \\
\text { IN AIR } \\
(\mathrm{min})\end{array}$ & \multicolumn{2}{|c|}{ IMPLANTED $(\mathrm{CH}) \times$} & \multicolumn{2}{|c|}{ NON-IMPLANTED $(\mathrm{CH}) \mathrm{x} \mid$} \\
\hline & $\begin{array}{c}(\mathrm{O}) /(\mathrm{C}) \\
\text { surface }\end{array}$ & $\begin{array}{c}(\mathrm{O}) /(\mathrm{C}) \\
\text { volume }\end{array}$ & $\begin{array}{c}(\mathrm{O}) /(\mathrm{C}) \\
\text { surface }\end{array}$ & $\begin{array}{c}(0) /(\mathrm{C}) \\
\text { volume }\end{array}$ \\
\hline & 0.051 & 0.039 & 0.042 & 0.061 \\
5 & 0.062 & 0.057 & 0.058 & 0.057 \\
245 & 0.100 & 0.105 & 0.165 & 0.119 \\
335 & 0.101 & 0.118 & 0.111 & 0.128 \\
1205 & 0.124 & 0.131 & 0.132 & 0.143 \\
2370 & 0.097 & 0.101 & 0.109 & 0.129 \\
5215 & 0.101 & 0.117 & 0.115 & 0.129 \\
\hline
\end{tabular}

Table 1: comparison between the oxidation rates of an implanted and pristine $(\mathrm{CH})_{x}$ sample versus time of exposition to air

Two main properties may be deduced from these results:

- polyacetylene doped by implantation with iodine is less sensitive to the oxidation of the air than the undoped sample. The reduction of sensitivity to the oxygen is however small and this observation is contradictory with the results of Weber et al./11/based on conductivity measurements.

- two stages may be distinguished: a fast oxidation stage and a saturation state reached after 4 hours exposure to the air.

The change of the oxidation rate corresponds to a redistribution of the oxygen which is initially purely superficial and diffuses into the bulk during the second stage. BuIk oxidation becomes larger than the surface oxidation in this stage.

The conductivity of these two samples has also been studied according to the exposure time to the air. Figure 3 clearly shows the two stages revealed by the RBS. We also find the lower rate of saturation of the implanted sample. However an inversion of the relative conductivities of the two samples may be observed in the very initial stage. In fact the larger conductivity of the implanted sample at the origin corresponds to a larger oxidation state in RBS. A possible explanation is that the irradiation produces a large number of dangling bonds by a radiolysis mechanism, which are saturated very quickly by the residual oxygen present in the vacuum system or during the transfer in the various measure cells.

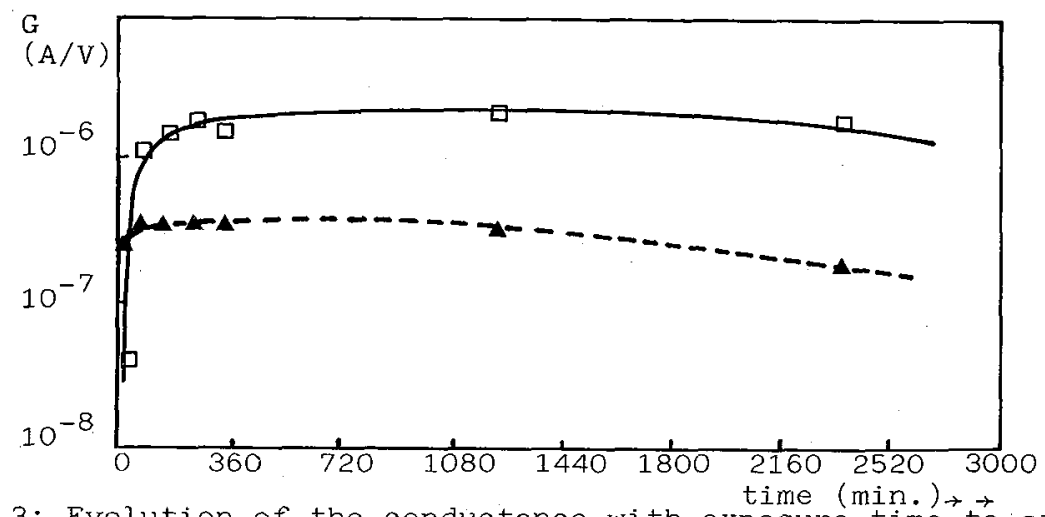

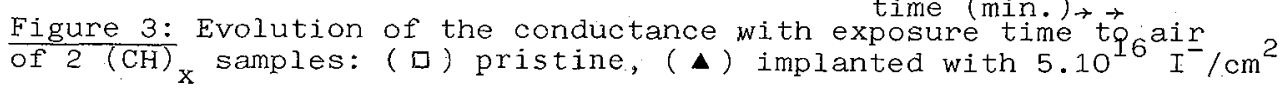


V - THERMAL STABILITY OF IMPLANTED POLYACETYLENE

We compared the stability of various doping species: Iodine, chlorine and $\mathrm{Fe}$ ions implanted together in a film of trans polyacetylene. For that purpose the implanted sample. was heated at $100^{\circ} \mathrm{C}$ in the analyzing chamber and the RBS spectrum was recorded at different annealing times (see figure 4). The total number of the different chemical species was deduced from the integrated areas of the different peaks and plotted versus time in figure 5 . This figure shows that the stability remains remarkable for times of the order of 10 hours whereas the dopant concentration had already been reduced by more than a factor 2 during this time in polyacetylene chemically doped with iodine $/ 12 /$. However the comparison with the dopant desorption kinetics of the Montpellier Group shows that the mechanism is more complicated in implanted samples what is quite understandable since implantation is basically a bulk doping process involving two processes for desorption: diffusion from the bulk to the surface of fibrils and then desorption from the fibril surface.

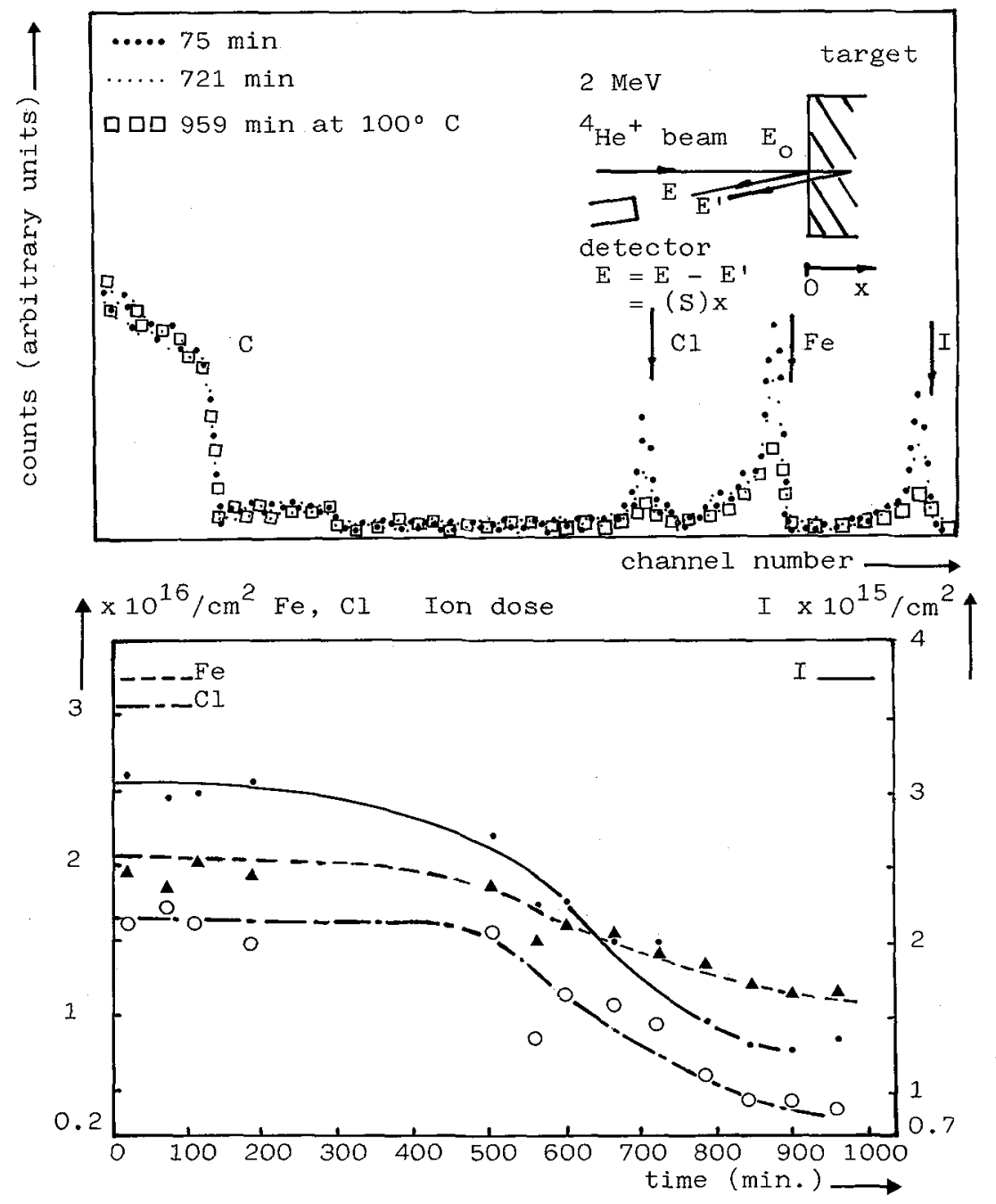

Figures 4 and 5: RBS spectrum and evolution of the number of the different implanted species versus annealing time at $100^{\circ} \mathrm{C}$ 


\section{VI - CONCLUSION}

Nuclear microanalysis techniques (nuclear reactions for hydrogen and RBS for heavier elements) have allowed the characterization of implanted polyacetylene films and the study of their stability. The combination of these techniques with electrical conductivity measurements clearly shows that two competiting processes are involved in the implantation process: material degradation and chemical doping. From the point of view of electrical properties the doping effect is dominating, but the rate of damage may be severe for large fiences and should probably be a limiting factor of the electrical activity. However the improved resistance to oxidation and the thermal stability are very interesting results. The first shows that the number of dangling bonds created by the radiolysis remains limited whereas the second indicates that the stability of the dopant stays acceptable for ordinary operating temperatures of electronic devices. A last remark is that $F e$ appears to be a very stable and electrically active specie in implanted specimens.

\section{ACKNOWLEDGMENTS}

It is a pleasure to acknowledge Dr. JP. THOMAS from the Institute of Physique Nucléaire de Lyon for performing the hydrogen profiling experiment and for helpful discussions.

\section{REFERENCES}

1 - WN. ALlEN, P. BRANT, CA. CAROSElla, JJ. de CORPO, CT. EWING, FE. SAALFELD and DC. WEBER Synthetic Metals, 1 (1979/80) 151

2 - JS. ABEL, H. MAZUREK, DR. DAY, EW. MABY, SD. SENTURIA, G. and MS. DRESSELHAUS Metastable Materials Formation by Ion Implantation Elsevier Science Publishing Co, Inc (1982) ST. Picraux and WJ. Choyke Editors

3 - J. DAVENAS,C. DUPUY, XU XING LONG, M. MAITROT, JJ. ANDRE et B. FRANCOIS LATDIC Conference Dublin (1982) to be publ. in Rad. Effects

4 - H. MAZUREK, DR. DAY, EW. MABY, JS. ABEL, SD. SENTURIA, G. and MS. DRESSELHAUS IBMM Conference Grenoble (1982) to be publ. in Nucl. Inst. and Methods

5 - H. SHIRAKAWA, S. IKEDA, POIYm. J. 2 (1971) 3 T. ITO, H. SHIRAKAWA, S. IKEDA, J. Polym. Sci. Lett., Polym. Chem. Ed. 12 (1974) 11

6 - B. FRANCOIS, M. BERNARD and JJ. ANDRE J. Chem. Phys. 75 (1981) 4142

7 - M. GAMOUDI, JJ. ANDRE, B. FRANCOIS and M. MAITROT J. de Physique 43 (1982) 953

8 - JP. THOMAS, C. PIJOLAS et M. FALLAVIER Revue de Physique Appliquée $13(1978) 433$

9 - T. VENKATESAN, SR. FORREST, ML. KAPLAN, PH. SCHMIDT, A. LOVINGER CA. MURRAY, R. ROBERTS and $H$. SCHONHORN IBMM COnference Grenoble (1982) to be publ. in Nucl. Inst. and Methods

10 - ILESANMI ADESIDA IBMM Conference Grenoble (1982) to be publ. in Nucl. Inst, and Methods

TC. SMITH Int. Conf. Ion Implantation (Equipment and Techniques) Berchtesgaden (1982) to be pub1. by Springer Verlag

11 - DC. WEBER, P. BRANT and CA. CAROSELLA Metastable Materials Formation by Ion Impiantation Elsevier Publishing Co, Inc (1982) ST. Picraux and WJ. Choyke Editors

12 - M. ROLLAND, S. LEFRANT, M. ALDISSI, P. BERNIER, E. RZEPKA and F. SCHUE J. of Electronic Materials 10 (1981) 4 